\title{
APPEAL TO BULGARIAN POLITICIANS THE DEMOGRAPHIC TRAGEDY OF BULGARIA
}

In May 2012, world political leaders committed to reducing global mortality from noncommunicable diseases (NCD) by $25 \%$ by 2025 . The complications of cardiometabolic diseases (CMD - atherosclerosis, hypertension, obesity, type 2 diabetes mellitus, and the metabolic syndrome) are accountable for nearly half of all NCD deaths making them the world's number one killer of humans, claiming 17.9 million lives each year. We have to educate people as well as politicians that by controlling risk factors, at least $80 \%$ of premature deaths from CMD could be avoided.

According to WHO data, we are among the world's leading countries in mortality from strokes and myocardial infarctions. According to Eurostat, Bulgaria is at first place in mortality among the countries in the European Union in 2016, as illustrated in the following graphic.
According to data from the Bulgarian National Statistical Institute, 108526 Bulgarians - a big Bulgarian city - have died from these and other diseases in 2018. Of these, 70546 were from strokes and myocardial infarctions, and 17462 from malignant tumors. In the same year, only 62197 children were born. The drop in the population is 46329 per year in a country with less than 7 million population. By dividing 108526 to 365 , there are 297 - the saddest arithmetic in Europe, so many people die every day in Bulgaria! And only 170 children are born daily. Hence, in Bulgaria the song of the goat - tragedy (Greek, tragoudia; tragos - goat, aedin - sing) - is continuing. Attention, the Sword of Damocles is falling mainly on the heads of the Bulgarians - the ethnicity that gives the name of our country.

Death rate in the EU Member States, 2016

(number of deaths per 100000 inhabitants)

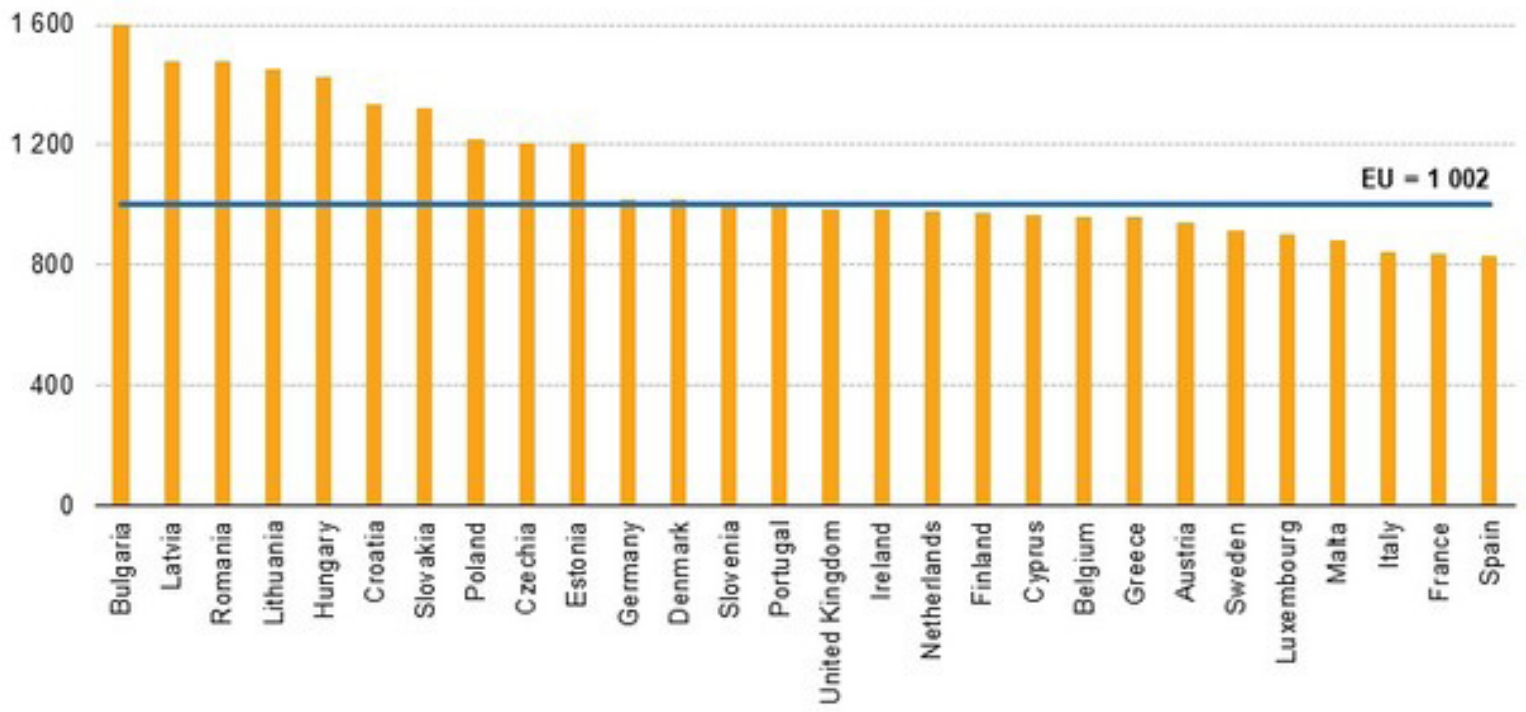


Bulgarian politicians, we have appealed many times (1-4), and now repeat (also see 5) that this is a truly urgent matter, which requires the development of an effective, long termed, science-based predictive and preventive medical and social strategy to overcome the demographic catastrophe (demostrophe). Otherwise, it would be Bulgaria without Bulgarians - the saddest folk song.

Bulgarian politicians, act now to tackle the pressure of obesity and its related cardiometabolic, oncological and neurodegenerative diseases. That will require a Herculean effort and financial support to overcome the demographic tragedy. Hercules needs to start work now! You do not have the luxury of delay or of waiting until the next election!

Bulgarian politicians, effective adipopolitics and adipoeconomics are urgently required, that is, the biggest and costly health problem - see 5, and data of the American Heart Association and the American Stroke Association:

In 2035, the number of Americans with cardiovascular diseases (CVD) is projected to rise to 131.2 million - 45 percent of the total USA population.

This means additional increases of medical costs:

$\begin{array}{lr}\text { High Blood Pressure } & 27.1 \text { million } \\ \text { Coronary Heart Disease } & 7.2 \text { million } \\ \text { Stroke } & 3.7 \text { million } \\ \text { Congestive Heart Failure } & 3.0 \text { million } \\ \text { Atrial Fibrillation } & 2.0 \text { million }\end{array}$

Bulgarian politicians, keep in mind-and-action the World Heart Federation's message: "We and our members believe in a world where heart health for everyone is a fundamental human right and a crucial element of global health justice."

We also believe that every heart beat and brain thought matter.

On behalf of the Bulgarian Society for Cell Biology

George N. Chaldakov, Chairman
1. Chaldakov GN, Aloe L, Tonchev AB, Rančić G, Hristova MG, Tunçel N, et al.

2. SOS for Homo sapiens obesus. A report of the 2nd International Symposium on Adipobiology and Adipopharmacology (ISAA), 23-25 October 2009, Varna, Bulgaria. Adipobiology 2010; 2:5-8.

3. Chaldakov GN. Healthy fat distribution-Healthy blood pressure: The Bulgarian message for the World Hypertension Day-2010. In: HealthEurope.org; May 2010.

4. Chaldakov GN. Jimmy Bell and the Little prince. A sciencein-fiction dedicated to the World Obesity Day. (in Bulgarian). In: www.eurochicago.com; 2017.

5. Chaldakov GN. Bulgarian politicians do not care how high fat life threatens the presence and the future of the nation. In: Weekly Newspaper "168 hours". Sofia, Bulgaria. 21-27 June 2018.

6. Hiriart M, Fiore M, Chaldakov GN. Save the Obese Man (SOS for Homo obesus). Effective adipopolitics and adipoeconomics are urgently required. An appeal to politicians. Adipobiology 2019;10:107-111. 